\title{
Determinan Sistem Aplikasi Keuangan Tingkat Instansi (SAKTI): Pendekatan Human-Organization-Technology (HOT) Fit Framework
}

\author{
Sudi Harnowo ${ }^{1}$ \\ Fakultas Ekonomi dan Bisnis \\ Universitas Mataram, Indonesia
}

\author{
Budi Santoso ${ }^{2}$ \\ Fakultas Ekonomi dan Bisnis \\ Universitas Mataram, Indonesia
}

\section{Embun Suryani ${ }^{2}$ \\ Fakultas Ekonomi dan Bisnis \\ Universitas Mataram, Indonesia}

\begin{abstract}
Surel : koyowongsingsoleh@gmail.com
ABSTRAK

Penelitian bertujuan untuk Penelitian ini dilakukan untuk menguji dan menganalisis pengaruh implementasi Sistem Aplikasi Keuangan Tingkat Instansi (SAKTI) terhadap kepuasan pengguna dan kondisi organisasi, pengaruh kondisi organisasi terhadap kepuasan pengguna, serta pengaruh kondisi organisasi dan kepuasan pengguna terhadap net benefits. Populasi penelitian ini adalah semua pengguna SAKTI lingkup Kementerian Keuangan di Provinsi Nusa Tenggara Barat sebanyak 105 dan sampel 43 dengan teknik pengambilan secara random sampling. Metode pengolahan data menggunakan Partial Least Square Structural Equation Modeling (PLS-SEM). Penelitian menghasilkan lima temuan pengaruh positif dan signifikan yaitu konstruk kualitas informasi terhadap kepuasan pengguna, kualitas sistem terhadap kondisi organisasi, kualitas layanan terhadap kondisi organisasi, kepuasan pengguna terhadap net benefits, dan kondisi organisasi terhadap net benefits.
\end{abstract}

Kata Kunci: $\quad$ SAKTI; HOT-Fit Framework; Net Benefits.

\section{Determinants of Agency Level Financial Application Systems (SAKTI): Human-Organization-Technology (HOT) Fit Framework Approach}

\begin{abstract}
This study was conducted to examine and analyze the effect of the implementation of the Sistem Aplikasi Keuangan Tingkat Instansi (SAKTI) on user satisfaction and condition of organization, condition of organization on user satisfaction, the effect condition of organization and user satisfaction on net benefit. The population of this study were all 105 SAKTI users within the Ministry of Finance in West Nusa Tenggara Province and 43 samples with a random sampling technique. Partial Least Square Structural Equation Modeling (PLS-SEM) was used to process the data. The study revealed there are five positive and significant influences: first, information quality on user satisfaction, second, system quality on condition of organization, third, service quality on condition of organization, fourth, user satisfaction on net benefits, and condition of organization on net benefits.
\end{abstract}

Keywords: $\quad$ SAKTI, HOT-Fit Framework, Net Benefits.

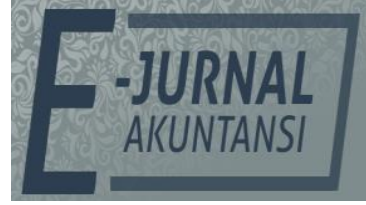

e-ISSN 2302-8556

Vol. 31 No. 3

Denpasar, Maret 2021

Hal. 769-781

DOI:

10.24843/EJA.2021.v31.i03.p19

PENGUTIPAN:

Harnowo, S., Santoso, B., \& Suryani, E. (2021).

Determinan Sistem Aplikasi

Keuangan Tingkat Instansi (SAKTI): Pendekatan Human-OrganizationTechnology (HOT) Fit

Framework. E-Jurnal Akuntansi, 31(3), 769-781

RIWAYAT ARTIKEL:

Artikel Masuk:

11 Januari 2021

Artikel Diterima:

25 Maret 2021

Artikel dapat diakses : https://ojs.unud.ac.id/index.php/Akuntansi/index 


\section{PENDAHULUAN}

Perubahan sistem informasi akuntansi adalah suatu proses yang wajar terjadi. Salah satu perubahan ini terjadi pada sistem informasi yang digunakan oleh satuan kerja pemerintah pusat dalam rangka menyelenggarakan kegiatannya, khususnya kegiatan yang berkaitan dengan tata kelola keuangan negara. Berbagai aplikasi pengelolaan keuangan negara yang saat ini digunakan antara lain RKAKL (Rencana Kerja Anggaran Kementerian Lembaga), SAS (Sistem Aplikasi Satker), SIMAK-BMN (Sistem Informasi Manajemen dan AkuntansiBarang Milik Negara), SAIBA (Sistem Akuntansi Instansi Berbasis Akrual) akan dieliminasi secara gradual untuk digantikan dengan suatu sistem terintegrasi yang diberi nama SAKTI (Sistem Aplikasi Keuangan Tingkat Instansi).

Ruang lingkup implementasi SAKTI digunakan bagi semua satuan kerja instansi pemerintah pusat yang mendapatkan anggaran dari APBN (Anggaran dan Pendapatan Belanja Negara). Tahap piloting implementasi SAKTI sudah dimulai sejak tahun 2015. Banyak pihak yakin bahwa pembaruan ini akan memberikan sumbangan perbaikan kinerja secara menyeluruh baik bagi pengguna maupun bagi organisasi. Sayangnya, keyakinan ini belum cukup memadai karena kurangnya dukungan data hasil penelitian. Hal ini mengundang munculnya kegelisahan akademik sehingga timbul pertanyaan benarkah implementasi SAKTI mampu meningkatkan kinerja bagi entitas yang menggunakannya.

Penelitian ini mengembangkan riset Amriani dan Iskandar (2019) yang meneliti Sistem Aplikasi Keuangan Tingkat Instansi (SAKTI) pada Satuan Kerja di Lingkungan Badan Pendidikan dan Pelatihan Keuangan (BPPK) dengan menggunakan model keberhasilan sistem informasi DeLone dan McLean. Model ini belum memiliki dimensi organisasi sehingga pengukuran kebermanfaat suatu sistem masih dapat ditingkatkan.

Hubungan antara teknologi-pengguna dan teknologi-organisasi adalah hubungan sebab-akibat yang dapat didekati dengan Signaling Theory. Teori ini digunakan untuk menjelaskan bagaimana fenomena keberadaan teknologi mempengaruhi pengguna dan organisasi untuk melakukan suatu aksi. Signalsignal sistem informasi berupa informasi baik berupa laporan, peringatan (warning), panduan (wizard), atau pemberitahuan dapat dikelompokkan ke dalam kualitas sistem itu sendiri, kualitas informasi, dan kualitas layanan/dukungan teknis yang diberikan.

$\mathrm{H}_{1}$ : Kualitas sistem SAKTI berpengaruh positif terhadap kepuasan pengguna.

Yusof et al. (2008) memproposisikan model pengukuran kontemporer yang diberi nama Human-Organization-Technology (HOT) Fit Framework. Model ini merupakan gabungan dari DeLone\&McLean Information System Success Model dan IT-Organizational Fit Model. Sebagai gabungan dari dua model, tujuan yang ingin diperoleh adalah untuk mendapatkan hasil pengukuran yang lebih komprehensif terhadap keberhasilan implementasi suatu sistem informasi. HOTFit Framework memiliki konstruk target berupa net benefits (manfaat bersih) yang menjadi ukuran final keberhasilan suatu sistem informasi. Beberapa peneliti telah menggunakan model HOT-Fit Framework namun sistem informasi yang menjadi tema penelitian adalah sistem optional dan tidak wajib untuk digunakan 
pada satuan kerja instansi pemerintah (Monalisa et al. 2018; Erimalata, 2016; Erlirianto et al. 2015)

Riset tentang isu-isu yang berkaitan dengan SAKTI masih belum terlalu tajam sehingga penelitian ini menjadi relevan dilakukan. Pengungkapan kelebihan dan kekurangan SAKTI lebih awal juga menjadi motivasi penelitian ini dilakukan mengingat SAKTI direncanakan akan digunakan secara nasional dan saat penelitian dilakukan belum seluruh kementerian/lembaga menggunakan SAKTI. Adanya IPMA (Importance-Performance Matrix Analysis) dapat digunakan untuk kepentingan manajerial dengan memfokuskan upaya perbaikan pada bagian-bagian yang dinilai masih belum optimal.

Keberhasilan sistem tidak hanya direfleksikan seberapa sering sistem digunakan, seberapa puas penggunanya, dan seberapa baik kualitas teknis teknologinya. Yusof et al. (2008) menambahkan dimensi organisasi sebagai setting tempat terjadinya interaksi antara user dan sistem. Penambahan ini dipengaruhi oleh Scott Morton (1991) yang mempopulerkan konsep kesesuaian antara teknologi informasi dan organisasi (IT-Organizational Fit).

Kesuksesan sistem informasi diukur melalui hubungan multidimensional yang memiliki enam variabel yaitu Kualitas Sistem (pengukuran sistem pemrosesan), Kualitas Informasi (pengukuran outputnya), Kualitas Layanan (pengukuran dukungan teknis atau layanan), Penggunaan Informasi (penggunaan atas output sistem informasi), Kepuasan Pengguna (respon pengguna terhadap output sistem informasi), dan Manfaat Bersih (dampak sistem informasi secara keseluruhan). Terdapat hubungan timbal balik antara penggunaan sistem informasi (system use) dengan manfaat bersih (net benefits), baik arah positif maupun negatif. Namun, asumsi ini berlaku jika sistem informasi yang dipakai bukanlah sistem yang wajib untuk digunakan dan tidak ada pilihan lain bagi pengguna maupun manajemen.

Monalisa et al. (2018) memberikan data bahwa kualitas sistem berbanding lurus dengan kepuasan pengguna. Hasil ini didukung pula oleh Akbar dan Mukhtar (2019). Artinya, tinggi rendahnya kepuasan pengguna ditentukan seberapa tinggi penilaian user terhadap kualitas sistem. SAKTI sebagai sebuah sistem yang wajib digunakan tidak memiliki opsi untuk tidak digunakan. Dengan demikian, dimensi pengguna (human) hanya dilihat dari kepuasan pengguna (user satisfaction) dan kurang tepat jika dilakukan evaluasi terhadap system use.

Sistem yang berkualitas juga dinilai dari seberapa baik kualitas informasi yang dihasilkan, terutama dalam rangka menghasilkan laporan yang dibutuhkan oleh pengguna. Hasil penelitian Akbar dan Mukhtar (2019), Wiyati dan Sarja (2019), Erlirianto et al. (2015) mengungkapkan bahwa kualitas informasi berdampak dominan pada kepuasan pengguna, berseberangan dengan hasil riset yang ditemukan oleh Monalisa et al. (2018).

$\mathrm{H}_{2}$ : Kualitas informasi SAKTI berpengaruh positif terhadap kepuasan pengguna.

Yusof et al. (2008) menjelaskan bahwa implementasi sistem informasi perlu dinilai dari dimensi kualitas layanan yang diterjemahkan sebagai the measures of technical support or service (pengukuran atas dukungan teknis atau layanan). Akbar dan Mukhtar (2019), Wiyati dan Sarja (2019), Erlirianto et al. (2015) menemukan data bahwa kualitas layanan berpengaruh positif dan 
signifikan terhadap kepuasan pengguna. Namun, Monalisa et al. (2018) tidak berhasil membuktikan hal tersebut sehingga membuat kesimpulan bahwa kualitas layanan tidak berpengaruh terhadap kepuasan pengguna. Kualitas layanan dalam penelitian ini diukur melalui penilaian user SAKTI terhadap dukungan teknis dan pemecahan masalah (trouble shooting) yang diberikan oleh pengembang SAKTI.

$\mathrm{H}_{3}$ : Kualitas layanan SAKTI berpengaruh positif terhadap kepuasan pengguna.

Sistem informasi adalah sesuatu yang ditambahkan (embedded) ke dalam sistem sosial di mana orang-orang dan lingkungan yang berbeda berinteraksi antara satu dan yang lainnya (Mohamadali dan Garibaldi, 2012). Sebagai alat bantu, sistem informasi diharapkan memudahkan suatu organisasi dalam rangka mencapai tujuannya. Untuk dapat mengoptimalkan potensi sebuah sistem informasi, organisasi perlu memiliki kesesuaian (fit) dengan sistem tersebut.

Yusof et al. (2008) menjelaskan penilaian dari aspek organisasi dikelompokkan menjadi struktur organisasi yang menyangkut sifat alamiah organisasi, hierarki dan divisi fungsional, dan lingkungan eksternal yang termasuk di dalamnya regulasi kebijakan pemerintah. Latar belakang berkembangnya HOT-Fit Framework adalah evaluasi sistem informasi kesehatan pada sektor privat sehingga perlu disesuaikan apabila digunakan untuk menguji kebermanfaatan suatu sistem informasi yang harus dipakai (wajib) pada wilayah publik. Yunis et al. (2017) memberikan bukti bahwa penggunaan sistem informasi berhubungan secara positif terhadap kinerja organisasi, sejalan dengan Poluan et al. (2014) dan Erimalata (2016).

$\mathrm{H}_{4}$ : Kualitas sistem SAKTI berpengaruh positif terhadap kondisi organisasi.

Kondisi organisasi merupakan keadaan suatu organisasi dilihat dari dimensi struktural dan dimensi lingkungan. Yusof (2015) memisahkan kedua variabel tersebut lebih ditekankan pada pemisahan faktor internal dan eksternal organisasi. Struktur organisasi mempengaruhi penggunaan sistem (system use) dan pengembangan sistem (system development), sedangkan lingkungan organisasi (environment) hanya mempengaruhi penggunaan sistem (system use). Dalam penelitian ini kondisi organisasi dipandang sebagai satu variabel yang memiliki sisi struktural dan sisi lingkungan.

$\mathrm{H}_{5}$ : Kualitas informasi SAKTI berpengaruh positif terhadap kondisi organisasi.

Keberadaan teknologi dalam suatu organisasi diyakini mampu memberikan kontribusi nyata. Tidak hanya memudahkan penyelesaian pekerjaan para pemakainya, namun teknologi juga membantu terwujudnya tujuan organisasi. Implementasi teknologi mampu mempengaruhi keputusankeputusan strategis manajemen, terutama yang berkaitan dengan optimalisasi penggunaan sumber daya organisasi. Berdasarkan argumentasi tersebut, maka dapat dirumuskan hipotesis sebagai berikut:

$\mathrm{H}_{6}$ : Kualitas layanan SAKTI berpengaruh positif terhadap kondisi organisasi.

Kepuasan pengguna tidak hanya dipengaruhi oleh seberapa baik sistem informasi (teknologi) tetapi juga dipengaruhi seberapa baik lingkungan organisasi. Erimalata (2016) menempatkan dukungan internal (biasanya departemen/divisi/seksi/bagian teknologi informasi) sebagai anteseden kepuasan pengguna. Yusof (2015) menemukan bahwa mutasi/pergantian pegawai yang dilakukan manajemen juga mempengaruhi kepuasan pengguna. 
$\mathrm{H}_{7}$ : Kondisi organisasi berpengaruh positif terhadap kepuasan pengguna.

Yusof et al. (2008) menyatakan bahwa "User Satisfaction are direct antecedent of Net Benefits". Krisbiantoro et al. (2015) membuktikan bahwa kepuasan pengguna berdampak positif dan signifikan terhadap net benefits, sejalan dengan Wiyati dan Sarja (2019), dan Abda'u et al. (2018) namun berseberangan dengan Erlirianto et al. (2015), Betri et al. (2017), dan Monalisa et al. (2018). Faktor subyektivitas pengguna sistem informasi terbukti mampu mempengaruhi temuan suatu penelitian. Kepuasan pengguna merupakan persepsi kebermanfaatan sistem informasi yang dipengaruhi oleh karakteristik pribadi pengguna. Contoh dari dampak secara individu misalnya penggunaan waktu yang lebih efisien, bertambahnya efektivitas dalam penyelesaian pekerjaan, meningkatnya kualitas pengambilan keputusan, dan berkurangnya kesalahan yang dilakukan oleh user. Semakin tinggi kepuasan pengguna, maka semakin termotivasi pula pengguna untuk menyelesaikan pekerjaannya secara efektif dalam waktu yang telah ditentukan.

$\mathrm{H}_{8}$ : Kepuasan pengguna berpengaruh positif terhadap net benefits.

Dimensi organisasi dalam penelitian ini diwakili oleh variabel kondisi organisasi sebagai gabungan dari konstruk struktur organisasi dan lingkungan organisasi dengan argumen bahwa sifat alami organisasi sektor publik lebih ditekankan pada kepatuhan terhadap regulasi dan ketiadaan ruang untuk memilih sistem informasi yang akan digunakan.

Erlirianto et al. (2015) menempatkan indikator dukungan top manajemen, strategi, kompetisi dan komunikasi untuk mengevaluasi organisasi menemukan hubungan yang positif dan signifikan terhadap net benefits. Hal ini didukung oleh Betri et al. (2017) yang memilih untuk menerjemahkan dimensi organisasi melalui variabel struktur organisasi. Bukti bahwa organisasi berhubungan secara positif dan signifikan terhadap net benefits juga dihasilkan oleh studi Ayuni et al. (2019) dan Monalisa et al. (2018), namun hal ini tidak berhasil dibuktikan oleh Akbar dan Mukhtar (2019).

$\mathrm{H}_{9}$ : Kondisi organisasi berpengaruh positif terhadap net benefits.

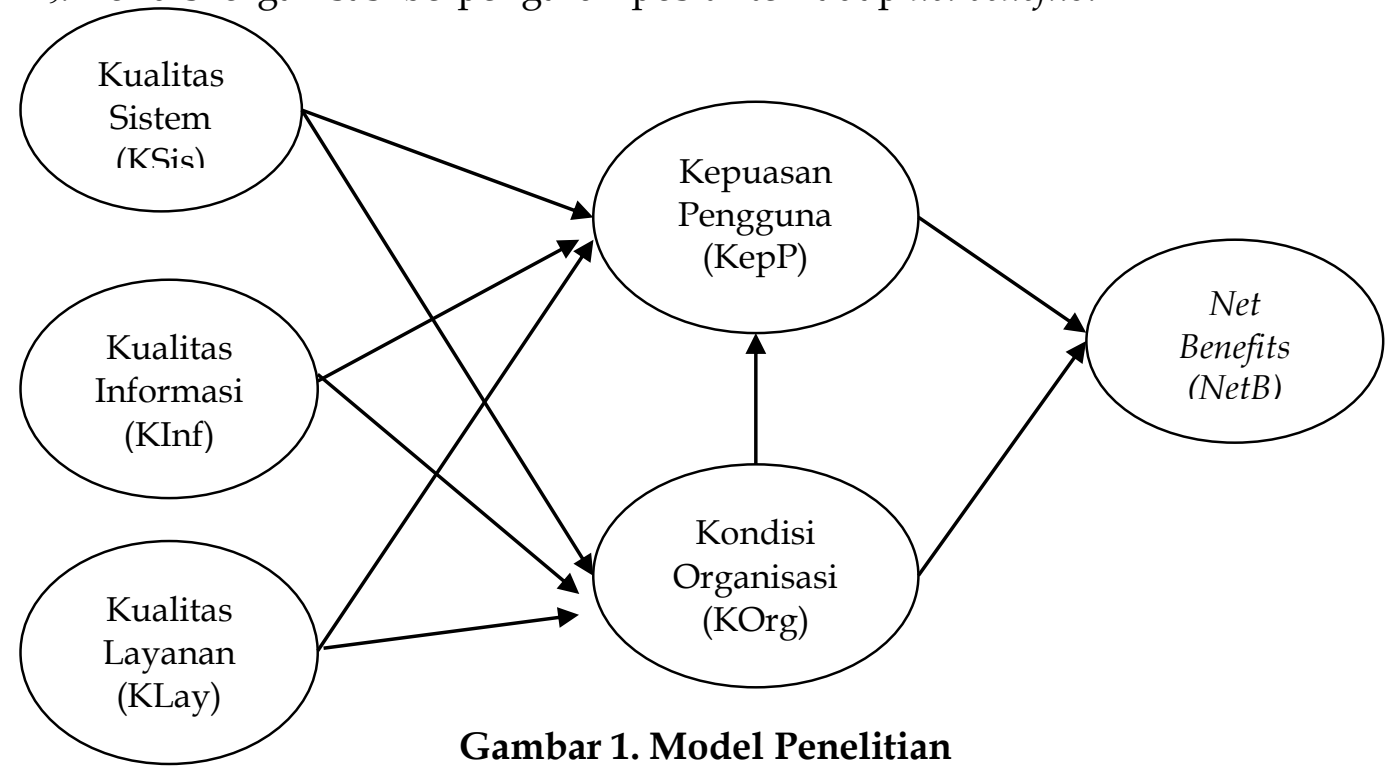

Sumber: Data Penelitian, 2020 


\section{METODE PENELITIAN}

Penelitian ini menggunakan pendekatan kuantitatif pada tingkat explanatory. Metode pengambilan sampel dalam penelitian ini memakai teknik random sampling. Hal ini didasari pada pertimbangan kondisi yang homogen dalam populasi yaitu seluruh anggota populasi adalah pengguna (user) sistem informasi. Meskipun pengguna tersebut mungkin memiliki perbedaan posisi pada masing-masing satuan kerja (staf/pejabat), namun penelitian ini bertujuan untuk mengukur persepsi individu sebagai pengguna teknologi. Pemilihan sampel dilakukan dengan cara cluster sampling. Masing-masing satuan kerja lingkup Kementerian Keuangan dipandang sebagai satu cluster dengan pertimbangan bahwa setiap satuan kerja memiliki karakter/kondisi organisasi yang berbeda-beda. Populasi pada penelitian ini adalah seluruh user SAKTI di seluruh wilayah Provinsi Nusa Tenggara Barat yang berjumlah 105 orang dengan sampel sebanyak 43 orang. Metode pengumpulan data yang digunakan adalah metode survei berupa kuesioner secara daring. Data yang terkumpul diolah dengan menggunakan PLS-SEM.

\section{HASIL DAN PEMBAHASAN}

Kuesioner penelitian disebarkan melalui media daring dan menghasilkan usable response rate 43 responden $(40,95 \%$ dari populasi). Rincian karakteristik responden dapat disajikan sebagai berikut;

Tabel 1. Rincian Karakteristik Responden

\begin{tabular}{lcc}
\multicolumn{1}{c}{ Keterangan } & Jumlah & Persentase \\
\hline Gender & & \\
Laki-laki & 28 & $68 \%$ \\
Perempuan & 15 & $32 \%$ \\
Usia & & \\
$<30$ tahun & 11 & $25,6 \%$ \\
$30-40$ tahun & 18 & $41,9 \%$ \\
$>40$ tahun & 14 & $32,5 \%$ \\
Pendidikan Terakhir & & \\
SD/SMP/SMA & 1 & $2,3 \%$ \\
Diploma/Sarjana & 39 & $90,7 \%$ \\
Magister/Doktor & 3 & $7,0 \%$ \\
\hline Sumber Data Pen
\end{tabular}

Sumber: Data Penelitian, 2020

Hasil uji reliabilitas pada menunjukkan bahwa seluruh konstruk memiliki nilai composite reliability lebih besar dari 0,7 sehingga kesimpulan yang dapat diambil adalah instrumen untuk mengukur konstruk yang bersesuaian adalah reliabel. Nilai AVE untuk seluruh konstruk juga di atas 0,5 sehingga dapat disimpulkan bahwa lebih dari $50 \%$ variance dapat dijelaskan. 
Tabel 2. Hasil Uji Discriminant Validity

\begin{tabular}{llllllll}
\hline & $\begin{array}{l}\text { Nilai } \\
\text { AVE }\end{array}$ & KInf & KLay & KOrg & KSis & KepP & NetB \\
\hline KInf & 0,675 & 0,822 & & & & & \\
KLay & 0,765 & 0,725 & 0,875 & & & & \\
KOrg & 0,765 & 0,637 & 0,660 & 0,875 & & & \\
KSis & 0,619 & 0,805 & 0,591 & 0,658 & 0,787 & & \\
KepP & 0,711 & 0,798 & 0,796 & 0,571 & 0,635 & 0,843 & \\
NetB & 0,722 & 0,704 & 0,528 & 0,637 & 0,695 & 0,705 & 0,850 \\
\hline
\end{tabular}

Sumber: Data Penelitian, 2020

Berdasarkan Tabel 2, dapat diketahui bahwa nilai akar kuadrat AVE (sisi diagonal) lebih tinggi jika dibandingkan dengan korelasi antar variabel. Dengan demikian dapat ditarik kesimpulan bahwa seluruh konstruk telah memenuhi Discriminant validity dan dapat dilakukan analisis data berikutnya.

Tabel 3. Nilai $\mathbf{R}^{2}$ dan Adjusted $\mathbf{R}^{2}$

\begin{tabular}{ccc}
\hline Konstruk & $\mathrm{R}^{2}$ & Adjusted $\mathrm{R}^{2}$ \\
\hline KOrg & 0,546 & 0,511 \\
KepP & 0,738 & 0,710 \\
NetB & 0,579 & 0,558 \\
\hline
\end{tabular}

Sumber: Data Penelitian, 2020

Data dalam Tabel 3, tersebut dapat dipahami bahwa konstruk Kondisi Organisasi dapat dijelaskan sebesar 51,1\% oleh konstruk prediktornya (Kualitas Sistem, Kualitas Informasi, Kualitas Layanan) dan sisanya sebesar 48,9\% dijelaskan variabel lain yang tidak ada dalam model. Adapun konstruk Kepuasan Pengguna dapat dijelaskan sebesar 71,0\% oleh konstruk prediktornya (Kualitas Sistem, Kualitas Informasi, Kualitas Layanan, dan Kondisi Organisasi) sedangkan sisanya sebesar $29 \%$ dijelaskan variabel lain. Selanjutnya, konstruk Net Benefits dapat dijelaskan sebesar 55,8\% oleh konstruk Kepuasan Pengguna dan Kondisi Organisasi sedangkan sisanya sebesar 44,2\% dijelaskan variabel lain. Konstruk Kepuasan Pengguna termasuk ke dalam kategori substansial (baik), sedangkan konstruk Kondisi Organisasi dan Net Benefits lebih dekat dalam kelompok moderat (sedang).

Tabel 4. Nilai $\mathrm{Q}^{2}$

\begin{tabular}{cccc}
\hline Konstruk & SSO & SSE & $\mathrm{Q}^{2}(=1-$ SSE $/$ SSO $)$ \\
\hline KOrg & 17,500 & 10,527 & 0,398 \\
KepP & 38,207 & 25,230 & 0,340 \\
NetB & 26,442 & 14,612 & 0,447
\end{tabular}

$\mathrm{SSO}=$ Sum of the Squared Observations

SSE $=$ Sum of the Squared-prediction Errors

Sumber: Data Penelitian, 2020

Berdasarkan data pada Tabel 4, konstruk Kondisi Organisasi, Kepuasan Pengguna dan Net Benefits memiliki nilai $\mathrm{Q}^{2}>0$. Artinya, model yang dibuat dalam penelitian ini sudah termasuk baik dan memiliki predictive relevance yang baik pula.

Berdasarkan hasil uji statistik pada Tabel 5, koefisien jalur kualitas sistem terhadap kepuasan pengguna adalah sebesar -0,009. Artinya, semakin meningkat kualitas sistem justru menurunkan kepuasan pengguna. Hasil $t$ statistics sebesar 0,055 dan $p$ value 0,956 menunjukkan bahwa tidak cukup data untuk menolak $\mathrm{H}_{0}$ 
yang artinya hipotesis kualitas sistem berpengaruh positif terhadap kepuasan pengguna tidak dapat diterima. Hasil penelitian ini tidak mendukung temuan riset yang dilakukan oleh Krisbiantoro, et al. (2015), Erimalata (2016), Betri et al. (2017), Abda'u et al. (2018), Monalisa et al.(2018), Akbar dan Mukhtar (2019), Wiyati dan Sarja (2019). Temuan ini sejalan dengan hasil riset Erlirianto, et al. (2015). Penentu kepuasan responden dalam menggunakan sistem tidak terletak pada kualitas sistemnya, tetapi faktor lain misalnya kualitas informasi. Kualitas sistem memiliki pengaruh negatif dan tidak signifikan terhadap kepuasan pengguna, sehingga null hypothesis gagal untuk ditolak. Dengan demikian prinsip dari HOT-Fit Framework tidak terbukti.

Tabel 5. Path Coefficients (Mean, STDEV, $t_{\text {-values, }} p$-values )

\begin{tabular}{lcccccl}
\hline & $\begin{array}{c}\text { Original } \\
\text { Sample } \\
(O)\end{array}$ & $\begin{array}{c}\text { Sample } \\
\text { Mean } \\
(M)\end{array}$ & STDEV & $\begin{array}{c}\text { T Statistics } \\
(\mid \text { OSTDEV } \mid)\end{array}$ & $\begin{array}{c}p \\
\text { Values }\end{array}$ & $\begin{array}{c}\text { Keterangan } \\
\text { (sig. 5\%) }\end{array}$ \\
\hline KSis->KepP & $-0,009$ & 0,014 & 0,159 & 0,055 & 0,956 & $\mathrm{H}_{1}$ ditolak \\
KInf->KepP & 0,490 & 0,454 & 0,243 & 2,021 & 0,043 & $\mathrm{H}_{2}$ diterima \\
KLay->KepP & 0,480 & 0,458 & 0,253 & 1,901 & 0,057 & $\mathrm{H}_{3}$ ditolak \\
KSis->KOrg & 0,403 & 0,410 & 0,198 & 2,036 & 0,042 & $\mathrm{H}_{4}$ diterima \\
KInf->KOrg & 0,015 & 0,006 & 0,267 & 0,056 & 0,955 & $\mathrm{H}_{5}$ ditolak \\
KLay->KOrg & 0,412 & 0,440 & 0,196 & 2,097 & 0,036 & $\mathrm{H}_{6}$ diterima \\
KOrg->KepP & $-0,053$ & $-0,008$ & 0,186 & 0,284 & 0,777 & $\mathrm{H}_{7}$ ditolak \\
KepP->NetB & 0,506 & 0,495 & 0,181 & 2,800 & 0,005 & $\mathrm{H}_{8}$ diterima \\
KOrg->NetB & 0,348 & 0,365 & 0,167 & 2,088 & 0,037 & $\mathrm{H}_{9}$ diterima \\
\hline
\end{tabular}

Sumber: Data Penelitian, 2020

Hasil dari penelitian ini menunjukkan bahwa koefisien jalur dari konstruk kualitas informasi terhadap kepuasan pengguna sebesar 0,490, dengan $t$ statistics 2,021 dan $p$ value 0,043. Artinya, ditemukan bukti bahwa semakin baik kualitas informasi maka semakin tinggi kepuasan pengguna. Hal ini mengkonfirmasi pendapat Yusof dan Yusuff (2013) dan sejalan dengan temuan penelitian Poluan et al. (2014), Erlirianto, et al. (2015), Abda'u et al. (2018), Monalisa et al. (2018), Akbar dan Mukhtar (2019), Wiyati dan Sarja (2019) namun berseberangan dengan hasil riset Erimalata (2016), dan Betri et al. (2017).

Salah satu variabel dalam model evaluasi implementasi sistem informasi HOT-Fit Framework adalah kualitas layanan. Assessment terhadap kualitas layanan lebih banyak pada penyedia sistem, dalam hal ini pembuat/pengembang aplikasi. Beberapa aspek teknis dibutuhkan pemeliharaan rutin seperti manajemen data base, update keamanan dan fitur/menu tertentu. Jika sistem mengalami gangguan, maka dukungan teknis untuk mengatasi permasalahan menjadi krusial. Dibutuhkan skill yang mumpuni, kecepatan waktu respon, ketepatan solusi, hingga empati terhadap pengguna sistem.

Selain layanan yang diberikan oleh pengembang aplikasi, kualitas layanan juga dinilai dari bagian/seksi tertentu dari satuan kerja yang menyediakan kebutuhan perangkat seperti laptop/komputer dengan spesifikasi tertentu dan dukungan perlengkapan jaringan (PMK-223/PMK.05/2015). Hal ini sekaligus sebagai manifestasi dukungan internal satuan kerja terhadap implementasi SAKTI. Sama halnya dengan bentuk-bentuk layanan pada 
umumnya, dibutuhkan keahlian tersendiri dalam mengatasi permasalahan, kecepatan respon dan empati dari pemberi layanan.

Hasil dari penelitian ini menunjukkan bahwa koefisien jalur dari konstruk kualitas layanan terhadap kepuasan pengguna sebesar 0,480 dengan $t$ statistics 1,901 dan $p$ value 0,057. Artinya, kualitas layanan berpengaruh secara positif namun tidak signifikan terhadap kepuasan pengguna. Data yang diperoleh dari penelitian ini belum cukup memadai untuk menolak $\mathrm{H}_{0}$ sehingga hipotesis kualitas layanan berpengaruh positif terhadap kepuasan pengguna tidak dapat diterima. Hasil penelitian ini berseberangan dengan temuan riset Erlirianto, et al. (2015), Betri et al. (2017), Abda'u et al. Akbar dan Mukhtar (2019), Wiyati dan Sarja (2019).

Keberadaan SAKTI sebagai pengganti sistem aplikasi yang sudah terlebih dahulu ada menuntut manajemen untuk membuat strategi baru. Organisasi perlu beradaptasi dengan pola baru penyelesaian pekerjaan. Manajemen perlu membuat berbagai perencanaan dan sistem pengendalian agar tujuan organisasi dapat tercapai bahkan dengan lebih baik lagi.

Hasil dari penelitian ini menunjukkan bahwa koefisien jalur dari konstruk kualitas sistem terhadap kondisi organisasi sebesar 0,403 dengan $t$ statistics 2,036 dan $p$ value 0,042 . Artinya, kualitas sistem berhubungan secara positif dan signifikan terhadap kondisi organisasi. Hasil penelitian ini mengungkapkan bahwa semakin baik kualitas sistem maka semakin baik pula kondisi organisasi, sejalan dengan temuan riset Poluan et al. (2014) namun berseberangan dengan penelitian Erlirianto, et al. (2015) dan Betri et al. (2017).

Hasil dari penelitian ini menunjukkan bahwa koefisien jalur dari konstruk kualitas informasi terhadap kondisi organisasi sebesar 0,015 dengan $t$ statistics 0,056 dan $p$ value 0,955 . Artinya, kualitas informasi berhubungan secara positif namun tidak signifikan terhadap kondisi organisasi. Data yang diperoleh dari penelitian ini belum cukup memadai untuk menolak $\mathrm{H}_{0}$ sehingga hipotesis kualitas informasi berpengaruh positif terhadap kondisi organisasi tidak dapat diterima. Hal ini berseberangan dengan temuan riset Poluan et al. (2014).

Penelitian ini menggabungkan kualitas layanan dari sisi teknis aplikasi SAKTI dan kualitas layanan pendukung yang diberikan oleh internal satuan kerja. Hal ini sesuai dengan ketentuan dalam Peraturan Menteri Keuangan Nomor 223/PMK.05/2015 tentang Pelaksanaan Piloting Sistem Aplikasi Keuangan Tingkat Instansi yang membagi layanan dalam dua jenis.

Hasil dari penelitian ini menunjukkan bahwa koefisien jalur dari konstruk kualitas layanan terhadap kondisi organisasi sebesar 0,412 dengan $t$ statistics 2,097 dan $p$ value 0,036. Artinya, kualitas layanan berhubungan secara positif dan signifikan terhadap kondisi organisasi. Hipotesis kualitas layanan berpengaruh positif terhadap kondisi organisasi dapat diterima.

Interaksi antara manusia (human) dan sistem informasi (technology) terjadi dalam lingkungan organisasi. Yusof et al. (2008) memandang perlunya kesesuaian antara ketiga faktor tersebut. Struktur organisasi dapat berubah mengikuti perkembangan terkini. Berbagai level manajemen dapat disesuaikan dengan adanya teknologi berupa sistem informasi baru. Beberapa fungsi mungkin perlu dieliminasi karena dapat digantikan oleh sistem namun 
organisasi perlu membentuk/meningkatkan fungsi pemeliharaan terhadap sistem.

Hasil dari penelitian ini menunjukkan bahwa koefisien jalur dari konstruk kondisi organisasi terhadap kepuasan pengguna sebesar -0,053 dengan $t$ statistics 0,284 dan $p$ value 0,777 . Artinya, kondisi organisasi berhubungan secara negatif namun tidak signifikan terhadap kepuasan pengguna. Data yang diperoleh dari penelitian ini belum cukup memadai untuk menolak $\mathrm{H}_{0}$ sehingga hipotesis kondisi organisasi berpengaruh positif terhadap kepuasan pengguna SAKTI tidak dapat diterima. Hal ini berseberangan dengan temuan riset Yunis et al. (2017), Krisbiantoro et al. (2015), Monalisa et al. (2018), Poluan et al. (2014) namun mendukung hasil penelitian Ayuni et al. (2019) dan Betri et al. (2017).

Yusof (2015) berpendapat bahwa mutasi/pergantian pegawai yang dilakukan manajemen juga dapat mempengaruhi kepuasan pengguna. Meskipun kebijakan tersebut tidak berhubungan secara langsung terhadap sistem informasi namun pengguna suatu sistem aplikasi tidak dapat bekerja mandiri dan memiliki ketergantungan dengan pengguna yang lain.

Konstruk akhir dari HOT-Fit Framework adalah net benefits. Variabel ini dapat memiliki banyak perspektif tergantung dari cara pandang peneliti. Yusof et al. (2008) meyakini bahwa kepuasan pengguna adalah faktor yang berpengaruh secara langsung terhadap Net Benefits. Pihak-pihak yang menjadi penyumbang net benefits termasuk di dalamnya adalah manajer, staf, pengembang sistem. Kepuasan pengguna merupakan persepsi kebermanfaatan sistem informasi yang dipengaruhi oleh karakteristik pribadi pengguna. Contoh dari dampak secara individu misalnya penggunaan waktu yang lebih efisien, bertambahnya efektivitas dalam penyelesaian pekerjaan, meningkatnya kualitas pengambilan keputusan, dan berkurangnya kesalahan yang dilakukan oleh user. Semakin tinggi kepuasan pengguna, maka semakin termotivasi pula pengguna untuk menyelesaikan pekerjaannya secara efektif dalam waktu yang telah ditentukan.

Hasil dari penelitian ini menunjukkan bahwa koefisien jalur dari konstruk kepuasan pengguna menuju net benefits sebesar 0,506 , dengan $t$ statistics 2,800 dan $p$ value 0,005. Artinya, ditemukan bukti bahwa semakin tinggi kepuasan pengguna maka semakin meningkat pula net benefits, sejalan dengan hasil riset Krisbiantoro et al. (2015), Wiyati dan Sarja (2019), dan Abda'u et al. (2018) namun berseberangan dengan Erlirianto et al. (2015), Betri et al. (2017), dan Monalisa et al. (2018).

Net benefits selain disumbangkan faktor pengguna (human) juga dipengaruhi oleh kondisi organisasi. Semakin baik kesesuaian antara teknologi dan organisasi maka semakin baik pula manfaat yang diperoleh dari implementasi sistem informasi. Dampak teknologi bagi organisasi dapat dilihat dari pengaruh sistem informasi terhadap kinerja organisasi misalnya adanya strategi dalam menyediakan layanan terbaik bagi pencapaian tujuan organisasi (Yusof dan Yusuff, 2013).

Dimensi organisasi dapat dilihat dari sisi struktur dan lingkungan (environment) Yusof et al. (2008). Struktur organisasi berkaitan dengan kondisi internal seperti dukungan top management, kepemimpinan, kerja sama tim, strategi, pengisian pegawai dan mutasi antar bagian. Adapun lingkungan 
organisasi berhubungan erat dengan politik, kebijakan pemerintah (regulasi), pendanaan, kompetisi.

Penelitian ini menggunakan variabel kondisi organisasi sebagai penyesuaian terhadap unit analisis yang berada pada satuan kerja pemerintah pusat. Hasil dari penelitian ini menunjukkan bahwa koefisien jalur dari konstruk kondisi organisasi menuju net benefits sebesar 0,348, dengan $t$ statistics 2,088 dan $p$ value 0,037. Artinya, ditemukan bukti bahwa semakin baik kondisi organisasi maka maka semakin meningkat pula net benefits. Hal ini sejalan dengan Erlirianto et al. (2015), Betri et al. (2019), Ayuni et al. (2019) dan Monalisa et al. (2018), namun berseberangan dengan hasil penelitian Akbar dan Mukhtar (2019).

Dimensi teknologi dibagi menjadi tiga konstruk yaitu kualitas sistem, kualitas informasi dan kualitas layanan. Kualitas informasi dapat dikonfirmasi mendukung Signaling Theory saat dikaitkan dengan kepuasan pengguna sebagai manifestasi dimensi human. Kepuasan pengguna muncul ketika manusia telah berinteraksi dengan sistem informasi. Tingkat kepuasan pengguna dapat naik atau turun berdasarkan bentuk-bentuk informasi yang dikirimkan oleh aplikasi SAKTI.

Signaling Theory pada mulanya berkembang di sektor privat di mana informasi yang dihasilkan pihak dalam (insider) diterima oleh pihak luar (outsider). Wujud informasi tersebut umumnya berupa laporan keuangan, informasi penerbitan sekuritas baru, dan lain sebagainya (Scott, 2015). Pada konteks penelitian ini, bentuk informasi dapat berupa wizard, panduan, kotak dialog, kotak peringatan (warning), termasuk di dalamnya berbagai laporan baik laporan keuangan maupun laporan manajerial.

Selanjutnya, ketika sinyal dari aplikasi SAKTI dihubungkan dengan kondisi organisasi, kualitas sistem dan kualitas layanan terbukti mampu mempengaruhi organisasi. Hal ini mendukung kebenaran Signaling Theory bahwa suatu informasi mampu mempengaruhi tindakan pihak yang menerimanya.

Tabel 6. Hasil Perhitungan IPMA

\begin{tabular}{lcc}
\hline \multicolumn{1}{c}{ Konstruk } & Importance & Performance \\
\hline KInf & 0,253 & 80,181 \\
KLay & 0,375 & 81,088 \\
KOrg & 0,321 & 86,016 \\
KSis & 0,125 & 75,993 \\
KepP & 0,506 & 81,928 \\
$\quad$ Rata-rata & 0,316 & 81,041 \\
\hline
\end{tabular}

Sumber: Data Penelitian, 2020

Data dalam Tabel 6, menunjukkan bahwa dengan menempatkan Net Benefits sebagai konstruk target, variabel kepuasan pengguna memiliki peran paling dominan dengan total effects sebesar 0,506. Sedangkan kualitas sistem menyumbangkan pengaruh yang paling kecil karena hanya memiliki total effects 0,125. Jika dilihat dari sisi kinerja (performance), kualitas sistem memiliki skor yang paling rendah yaitu 75,993. Angka ini di bawah nilai rata-rata seluruh konstruk yang berada level 81,041. Dengan demikian, pengembangan SAKTI dapat difokuskan pada kualitas sistem sehingga mampu meningkatkan kebermanfaatan implementasi sistem secara keseluruhan. Model klasik dalam 
pengambilan keputusan adalah pilihan terbaik mengingat pengelolaan keuangan negara pada institusi pemerintahan lebih berorientasi pada peraturan perundang-undangan yang berlaku (regulation-oriented).

\section{SIMPULAN}

Penelitian menghasilkan lima temuan pengaruh positif dan signifikan yaitu konstruk kualitas informasi terhadap kepuasan pengguna, kualitas sistem terhadap kondisi organisasi, kualitas layanan terhadap kondisi organisasi, kepuasan pengguna terhadap net benefits, dan kondisi organisasi terhadap net benefits. Data IPMA menunjukkan bahwa kualitas sistem menjadi bagian terlemah SAKTI sehingga pengembang aplikasi dan para pengambil kebijakan dapat memfokuskan upaya perbaikan pada area tersebut.

Response Rate penelitian ini cukup dekat dengan ambang batas minimal. Peneliti selanjutnya dapat meningkatkan Response Rate sehingga statistical power dapat lebih baik. Wawancara secara terbatas dapat ditambahkan untuk lebih menangkap persepsi para pemangku kepentingan aplikasi SAKTI. Kuesioner sebagai alat untuk memperoleh data memiliki kelemahan intrinsik karena tidak ada interaksi dua arah antara peneliti dan responden. Dengan mengadakan wawancara, hal lain diluar item-item pertanyaan dapat digali lebih jauh.

\section{REFERENSI}

Abda'u, P. D., Winarno, W. W., \& Henderi, H. (2018). Evaluasi Penerapan SIMRS Menggunakan Metode HOT-Fit di RSUD dr. Soedirman Kebumen. INTENSIF: Jurnal Ilmiah Penelitian Dan Penerapan Teknologi Sistem Informasi, 2(1), 46-56. https:/ / doi.org/10.29407/intensif.v2i1.11817

Akbar, R., \& Mukhtar, M. (2019). Evaluasi e-Tracer Study menggunakan HOT (Human-Organization-Technology) Fit Model. Jurnal JTIK (Jurnal Teknologi Informasi Dan Komunikasi), 3(2), 46-51. https:// doi.org/10.35870/jtik.v3i2.86

Amriani, T. N., \& Iskandar, A. (2019). Analisis Kesuksesan Implementasi Sistem Aplikasi Keuangan Tingkat Instansi (SAKTI) pada Satuan Kerja di Lingkungan Badan Pendidikan dan Pelatihan Keuangan (BPPK). Kajian Ekonomi Keuangan, 3(1), 55-74.

Betri, T. J., Utami, E., \& Al Fatta, H. (2017). Perancangan Arsitektur Aplikasi Learning Management System Di Universitas Slamet Riyadi. Indonesian Journal of Applied Informatics, 2(1), 1-16. https:// doi.org/10.20961/ijai.v2i1.16606

Dewinta Ayuni, N. W., Dewi, K. C., \& Suwintana, I. K. (2019). Hot Fit Pada Sistem E-Learning Politeknik Negeri Bali Dengan Self Efficacy Sebagai Variabel Mediator. Jurnal Matematika, 9(2), 66-77. https:/ / doi.org/10.24843/jmat.2019.v09.i02.p112

Erimalata, S. (2016). Pendekatan Hot-Fit Framework dalam Generalized Structural Component Analysis pada Sistem Informasi Manajemen Barang Milik Daerah: Sebuah Pengujian Efek Resiprokal. Jurnal Akuntansi Dan Investasi, 17(2), 141-157. https://doi.org/10.18196/jai.2016.0051.141157

Erlirianto, L. M., Ali, A. H. N., \& Herdiyanti, A. (2015). The Implementation of 
the Human, Organization, and Technology-Fit (HOT-Fit) Framework to Evaluate the Electronic Medical Record (EMR) System in a Hospital. Procedia Computer Science, 72, 580-587. https:// doi.org/10.1016/j.procs.2015.12.166

Peraturan Menteri Keuangan Nomor 223/PMK.05/2015 tentang Pelaksanaan Piloting Sistem Aplikasi Keuangan Tingkat Instansi.

Krisbiantoro, D., Suyanto, M., \& Taufiqluthfi, E. (2015). Evaluasi Keberhasilan Implementasi Sistem Informasi Dengan Pendekatan Hot Fit Model ( Studi Kasus: Perpustakaan STMIK AMIKOM Purwokerto ). Konferensi Nasional Sistem \& Informatika, 896-901.

Monalisa, S., Anggara, P. P., \& Kurnia, F. (2018). Analisis Kesuksesan Penerapan Sistem Administrasi Akademik Menggunakan Human Organization Technology Fit Model. Jurnal Ilmiah Rekayasa Dan Manajemen Sistem Informasi, 4(1), 36-41.

Poluan, F., Lumenta, A., \& Sinsuw, A. (2015). Evaluasi Implementasi Sistem ELearning Menggunakan Model Evaluasi Hot Fit Studi Kasus Universitas Sam Ratulangi. Jurnal Teknik Informatika, 4(2), 1-6. https:// doi.org/10.35793/jti.4.2.2014.6985

S-Mohamadali, N. A. K., \& Garibaldi, J. M. (2012). Understanding and addressing the "FIT" between user, technology and organization inevaluating user acceptance of healthcare technology. HEALTHINF 2012 - Proceedings of the International Conference on Health Informatics, 119-124. https:/ / doi.org/10.5220/0003696901190124

Scott, W. R. (2015). Financial Accounting Theory (Seventh Ed). Ontario: Pearson.

Wiyati, RK; Sarja, N. L. A. K. (2019). Evaluasi Penerapan Sistem Informasi Absensi Online Dengan HOT FIT Model. Jurnal Teknologi Informasi Dan Komputer, 5(1), 1-9.

Yunis, M., Tarhini, A., \& Kassar, A. (2018). The role of ICT and innovation in enhancing organizational performance: The catalysing effect of corporate entrepreneurship. Journal of Business Research, 88(June 2017), 344-356. https:// doi.org/10.1016/j.jbusres.2017.12.030

Yusof, M. M. (2015). A case study evaluation of a Critical Care Information System adoption using the socio-technical and fit approach. International Journal of Medical Informatics, 84(7), 486-499. https:// doi.org/10.1016/j.ijmedinf.2015.03.001

Yusof, M. M., Kuljis, J., Papazafeiropoulou, A., \& Stergioulas, L. K. (2008). An evaluation framework for Health Information Systems: human, organization and technology-fit factors (HOT-fit). International Journal of Medical Informatics, 77(6), 386-398. https:// doi.org/10.1016/j.ijmedinf.2007.08.011

Yusof, M. M., \& Yusuff, A. Y. A. (2013). Evaluating E-government system effectiveness using an integrated socio-technical and fit approach. In Information Technology Journal (Vol. 12, Issue 5, pp. 894-906). https:// doi.org/10.3923/itj.2013.894.906 